\title{
1974-A Year of Inflation, Production Cutbacks, and Oil-Induced Payments Deficits
}

\author{
NORMAN N. BOWSHER
}

\section{Ir}

N TERMS of economic achievement, the year 1974 was like a "hangover", with current performance bem low potential as a result of previous excesses. Inflation intensified, production declined, and the unemployment rate rose. It was a year characterized by numerous adverse developments as well as one of adjustment following a prolonged expansionary spree beginning in the mid-1960s.

Economic developments in any year are heavily influenced by actions taken in previous years. Price increases in 1974, which were sizable indeed, resulted, in part, from previous actions which stimulated aggregate demand. At the same time, the ability of the economy to satisfy this expanding demand was reduced by developments such as the adverse worldwide food situation, the limiting of oil output by producing nations, and price controls. Although most of these developments occurred before 1974, they had important impacts on the timing and magnitude of price increases in 1974.

Production in 1974 also reflected earlier developments. Previous expansionary actions had pushed up output rapidly to levels above maximum efficiency in many industries. This situation was aggravated by the combination of price controls and environmental improvement regulations which discouraged expansion and caused abandonment of some marginal productive processes. Also, sharply higher prices for some items in late 1973, gasoline for example, caused consumers to alter their consumption patterns. This, in turn, caused production to decline in certain lines, while in other markets shortages could be avoided only by sharply higher prices.

Judged solely by output and price performances, the year 1974 was a dismal failure. Prices rose faster than in any year since the inflation began in 1965 , and real output of goods and services fell substantially. Yet, despite the course of events leading up to the year and the momentum of inflationary pressures as the year began, there were some encouraging developments during the year. Acceleration of inflation

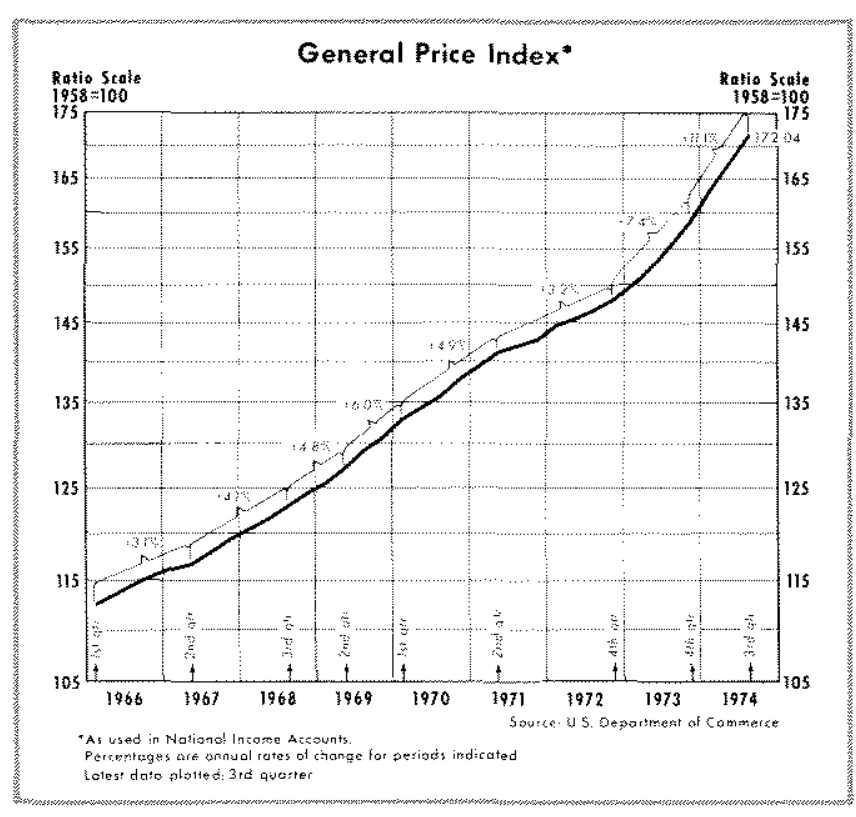

was apparently halted. Although production declined, a deep recession was avoided. Economic freedom was restored with the removal of restraints on wages and prices, and the process of eliminating shortages induced by the controls began as firms once again responded to incentives provided by market forces.

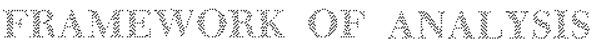

The chief monetary development in the years preceding 1974 was a sustamed rapid growth in the nation's money stock. This earlier growth in the money stock is reviewed here because it is consistent with the view that the trend growth of money over a four- or five-year period has a dominant effect on the trend of prices. Marked changes in the growth rate of money around a trend, lasting about two quarters or more, have a significant influence on production and employment, but as the new trend is fully reflected in prices, the production and employment effects disappear.

The analysis used here does not deny the existence of many exogenous forces which may have short-run 


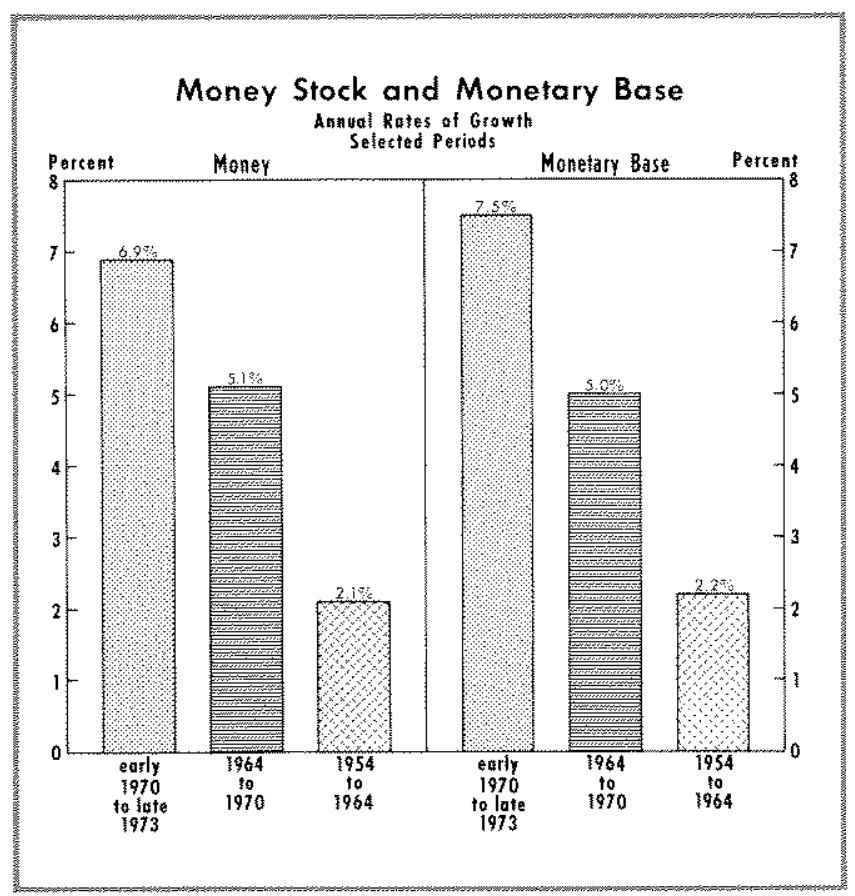

economic impacts. These forces include the operation of an oil cartel, a widespread crop failure, and some institutional changes, such as elimination of price and wage controls. Similarly, fiscal actions have economic effects which generally last for several quarters.

\section{A COONOND}

On balance, the actions of the Government were very stimulative to the economy in the four years preceding 1974. The nation's money stock was increased at an average 7 percent annual rate from early 1970 (a period marked by recession) to the end of 1973 . By comparison, from 1964 (the last year of relatively stable prices) to 1970 , the money stock rose, on average, at a 5 percent rate; in the previous decade money increased at a 2 percent average rate.

The growth of the money stock is determined within a narrow band by the growth of the monetary base. The base, the primary sources of which are Federal heserve credit and monetary gold stock, rose at a 7.5 percent rate from early 1970 to the end of 1973. Earlier, the base had risen at a 5 percent rate from 1964 to 1970 , and at a 2 percent pace in the previous ten years.

Fiscal actions of the Govemment were also expansionary in the four years preceding 1974. Government expenditures, using the national income accounts budget, rose at about a 9 percent annual rate from early 1970 to the end of 1973 . This was about the same as the rapid pace of the 1964 to 1970 period, which included the sizable military build-up for Vietnam. From 1955 to 1964, Government outlays increased at a 6.3 percent rate. Average tax rates had been reduced through tax reform, cuts in excise tax rates, increases in personal tax exemptions and restoration of an investment tax credit. The combined effect of these fiscal actions was to shift the national income accounts budget from an $\$ 8$ billion surplus in 1969 to four consecutive deficits in the period from 1970 through 1973 , averaging over $\$ 14$ billion per year.

The stimulative policy actions in the 1970 through 1973 period came in response to a number of factors. It was widely thought in 1970 and 1971 that economic stimulation was desirable in order to spur production and employment. In addition, from August 1971 until early 1974, the nation went through various phases of controls on wages and prices. With the apparent restraint on prices, it was felt by some that the more conventional tools of policy might be devoted to encouraging economic expansion and growth without the risk of more inflation. This view was reinforced by the fact that unemployment was 5 percent or more of the labor force until the spring of 1973. For a brief period in the summer and early fall of 1973 , restraint was exerted; for example, the money stock rose at a slow 1.5 percent annual rate from June to October. However, later in the year, with the sharp markup of oil prices, relaxation of policies again appeared desirable to some analysts in order to attempt to moderate production cutbacks.

In response to the expansionary monetary and fiscal developments, total spending on goods and services accelerated markedly after 1970 . Gross national product had risen at a 4.2 percent annual rate from the fall of 1969 to the end of 1970 , or at about the same pace as productive capacity. During 1971 GNP rose 9.2 percent, during 1972 it climbed 11.2 percent, and in 1973 it expanded 11.6 percent.

In 1971 and 1972 , the rate of inflation was lower than in the two previous years, despite the acceleration in the pace of total spending on goods and services. Overall prices, as measured by the GNP deflator, had risen at a 5.3 percent annual rate from the end of 1968 to the end of 1970 . During 1971, prices increased at a 3.5 percent rate, the slowdown reflecting at first the delayed effects of monetary discipline in 1969 and early 1970 . Later in the year reported prices also reflected the initial impact of controls on wages and prices which began with the freeze in August 1971. During 1972, under the continuing pressure of controls, reported prices rose at a 3.7 percent rate. 
In 1973, however, as underlying inflationary pressures intensified, controls on prices began crumbling. In addition, prices were jolted upward by a number of random shocks, such as the reduced international price of the dollar and poor harvests in many countries which led to an increased foreign demand for domestically-produced food. Moreover, an energy supply problem increased sharply the prices of energy and energy-related products late in the year. As a result, the rate of inflation during 1973 accelerated during each quarter, rising from a 4 percent rate in late 1972 to an 8.6 percent pace in the final quarter of 1973. On average, the rate of inflation was 7.4 percent during 1973.

Production, employment, and real income expanded markedly in 1971 and 1972. From the fourth quarter of 1970 to the fourth quarter of 1972 , total real output, for example, rose at a 6.4 percent annual rate, or double the rate experienced in the previous five years.

Although production had been rising rapidly, during 1971 and 1972, growth in productive facilities had been hampered by an outlook for diminished profits on invested capital resulting from price controls and environmental laws, As a result, 1973 found a number of firms operating at levels exceeding long-run maximum efficiency. Also, near year-end a reduction in oil supplies and the effects of energy conservation measures affected output adversely. Hence, growth in real output, which was at a high 9.5 percent rate in the first quarter, slowed to a 2 percent pace in the last three quarters of 1973.

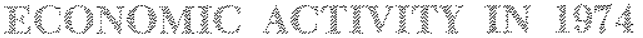

As 1974 began, economic problems were numerous and appeared to be intensifying. The growth rate in total spending had been rapid, probably excessive, for several years. As a result, production had risen to levels where marginal costs were rising rapidly in many industries, and prices were being bid-up at progressively faster rates. At the same time, price and output developments continued to be affected adversely by a number of exogenous forces, such as the oil and food situations, controls on prices, and environmental improvement and safety regulations. Adding to the economic woes was uncertainty over the political situation in this country. In brief, strong demands for goods and services were pressing against a limited and contracting supply of goods and services, a situation conductive to an inflationary surge.

In such a climate, restraint was believed appropriate. Monetary developments became less stimulative, but the shift was, on the whole, moderate, ${ }^{1}$ Inflation, which was rapid, did peak and appeared to be receding late in the year. A severe depression, which many feared would develop if the inflation were resisted, did not occur, although cutbacks in output developed.

\section{Speradistage}

In most years the key economic variable has been the rate of growth of demand for goods and services. In order to sustain expansion in output, employment, and real income, demand for goods and services must be increasing. In 1974, however, it was demonstrated that an increasing demand is not sufficient to prevent a decrease in output and real income, especially in the short run. Although growth of aggregate demand for goods and services decelerated somewhat in the year, supply constraints and the costs of adjusting to changing spending patterns retarded production. Output and real income declined, demand remained excessive, and prices were bid-up even higher.

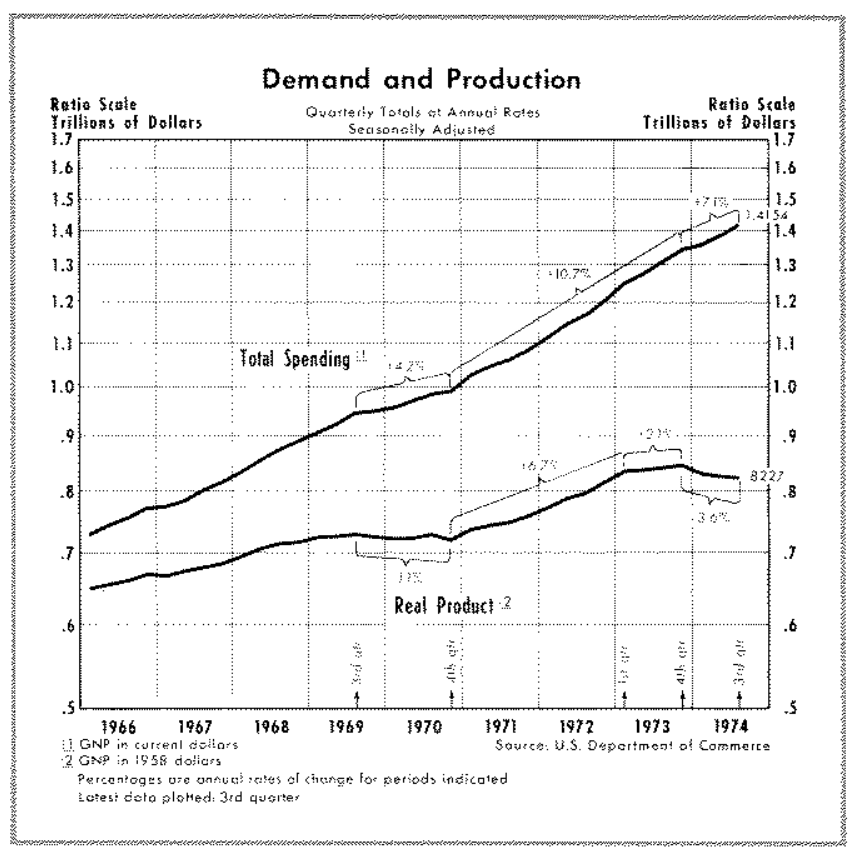

Total spending on goods and services expanded at a 7 percent annual rate in the first three quarters of 1974. This was less than the 1970-73 surge, which averaged 10 percent, but slightly greater than the 6.2 percent trend rate from 1955 to 1970 ; it also exceeded

1Chairman Arthur F. Burns of the Board of Governors of The Federal Reserve System testified on October 10 to the Joint Economic Committee of Congress: "The policy that we have pursued represents a middle course. We have tried to apply the monetary brakes firmly enough to get results, but we have also been mindful of the need to allow the supply of money and credit to keep expanding moderately." 
the 3.5 to 4 percent estimated long-run trend growth potential of productive capacity. New orders of manufacturing firms rose at a rapid 16 percent annual rate in the first nine months of 1974 (latest data available). During the period it was reported that a sizable portion of these firms were operating at effective capacity.

Market forces allocated the increases in aggregate demand broadly. However, since the distribution was influenced by factors such as energy limitations, inter. est rate ceilings, price controls, and Governmental subsidies, some types of purchases rose much more slowly than others or even declined.

Consumers, on balance, increased their spending substantially. Personal consumption expenditures rose at a 12 percent annual rate in the first three quarters of 1974, despite marked cutbacks in spending on auto. mobiles. The decline in auto sales can be explained, in part, by the fact that production could not shift toward models that use less gas as rapidly as consumer demands changed in response to higher gasoline prices. Also, higher costs of producing autos brought about by required environmental and safety equipment contributed to the depressed sales. Outlays for new housing also declined, reflecting customer reaction to the higher costs of construction and land, and the large supply of unsold units. There were market interruptions to the financing of houses, resulting from state usury laws, regulations of interest rates paid by savings institutions, and the higher market interest rates accompanying the inflation.

Business spending on plant and equipment rose at a 12 percent annual rate in the first three quarters of 1974. Many firms operated at or above optimum levels most of the year with sizable order backlogs reported. Partially reflecting the strong demands, many firms found it difficult to maintain or build inventories until the fall of the year. In the aggregate, the rate of inventory accumulation slowed from $\$ 15$ billion in 1973 to a $\$ 9$ billion annual rate in the third quarter of 1974 .

Government purchases of goods and services also rose at a 12 percent annual rate in the first three quarters of 1974. Spending by state and local gov* ermments continued their upward trend, and there was an increase in Federal defense outlays. Social programs and other nondefense spending increased at

\footnotetext{
${ }^{2} \mathrm{~A}$ survey of 155 economists from manufacturing forms by the National Association of Business Economists in August and September found that 65 percent of the firms were currently operating at effective capacity, 29 percent were below effective capacity and 6 pereent did not know.
}

a 14 percent rate, despite the "austerity" program implemented to resist inflation.

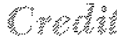

The growth in spending was facilitiated by a substantial expansion of credit outstanding. Total commercial bank credit rose at a 10.3 percent annual rate in the first eleven months of 1974, compared with a 9.6 percent trend rate in the previous decade. In addition, sizable amounts of credit were extended by life insurance companies, mutual savings banks, and savings and loan associations. There was also a substantial volume of borrowing in the money and capital markets on commercial paper and bonds. Most of the additional funds supplied came from saving, but a part was created by the banking system. Business ad vances, residential mortgage loans, consumer credit, and Government indebtedness (including agencies) all expanded. Partially reflecting the market constraints mentioned above, real estate loans grew at a relatively slow pace.

The demand for credit increased more rapidly than supply in the first seven months of 1974. The huge demands for funds reflected not only a high level of activity in many sectors, but also rising prices and expectations of still higher prices. As a result, interest rates rose sharply, especially on short-tern obligations. The average rate at which commercial banks lent dayto-day Federal funds rose from about 10 percent in December 1973 to nearly 13 percent in July. Over the same period, the average yield on prime 4 - to 6 month commercial paper went up from 9 percent to 11.7 percent, and interest rates on highest grade seasoned corporate bonds increased from 7.7 percent to 8.7 percent.

After July, interest rate developments were mixed, Rates on most short-term instruments moved lower, while yields on long-term obligations continued to rise until late in the year, when they too began to decline. The average Federal funds rate fell from almost 13 percent in July to less than 9 percent in early December, and the commercial paper rate dropped from 11.7 percent to 9 percent in the same period. The yield on highest grade corporate bonds, however, contimued to rise from the 8.7 percent July average to 9.4 percent in the week ended October 11. After mid-October these rates also declined, and averaged about 8.9 percent in early December.

During 1974, there were somewhat fewer institutional obstacles distorting credit flows than there were in the 1966 or the $1969-70$ episodes of rapidly rising 


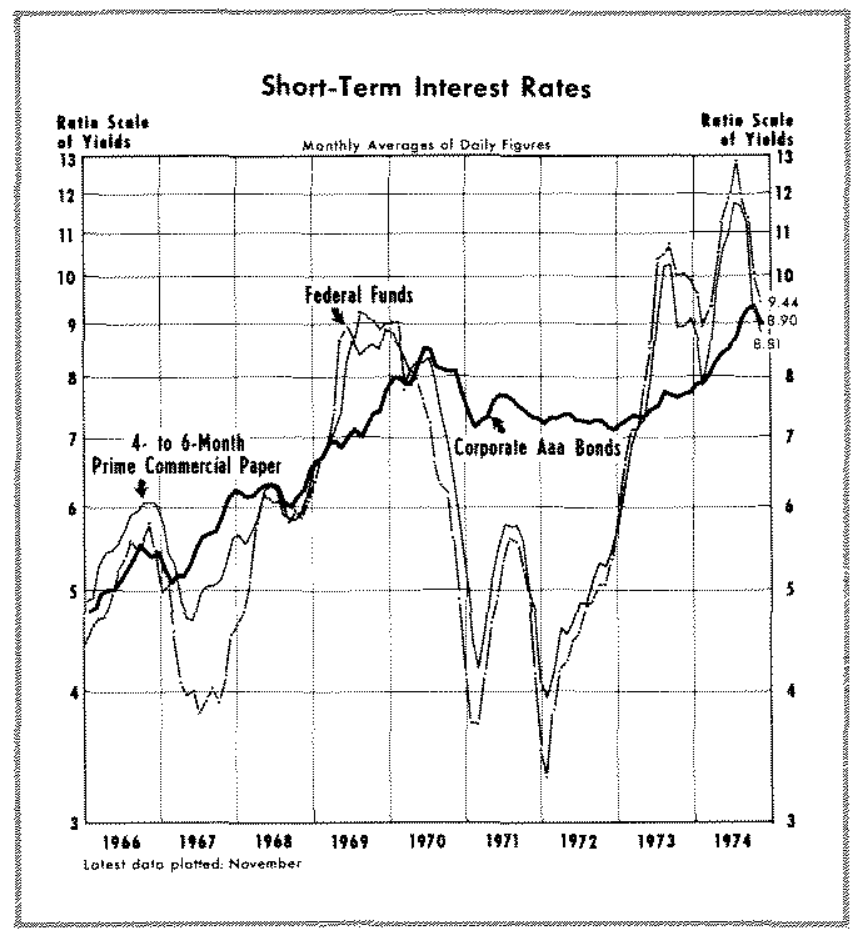

interest rates. For example, ceiling rates on large CDs (over 30 days) were lifted, some state usury laws were relaxed, and rates that thrift institutions could pay to attract savings were slightly higher. These developments may have permitted market interest rates to be bid higher than they otherwise would have been, but credit was generally available and the severe wrenching of a widespread "credit crunch" was avoided.

\section{produchan}

Production declined markedly in 1974. From the fourth quarter of 1973 to the third quarter of 1974 , gross national product in real terms fell at a 3.6 percent annual rate. Data available in early December indicate a further drop will be recorded in the fourth quarter. By contrast, real output rose at a 4 percent average rate in the decade from 1962 to 1972 , and slowed to a 2 percent rate from the first to the fourth quarter of 1973. During the last previous economic contraction, from late 1969 to late 1970 , real output declined at only a 1 percent annual rate, despite an accompanying major automobile strike.

There has been considerable controversy regarding the basic causes of the reported slowdown in output growth in 1973 and the sharp decline which occurred in 1974. Some analysts contend that the slower growth and decline resulted in large measure from weak aggregate demand. Other analysts contend it was due mainly to factors affecting overall supply.
Both demand and supply factors probably contributed to the production cutbacks, but supply factors played a much greater role than in other post-World War II production declines. Aggregate demand growth, as noted before, remained fairly strong in 1974, although it was more moderate than during the 1970-73 surge in spending. The chief explanation then as to why the response of real output to demand growth differed from earlier experiences appears to be in a changed supply situation. Numerous constraints had been placed on the ability of business firms to produce, and these restrictions have become much more burdensome in the last few years.

For example, environmental and safety requirements were imposed on a broad scale. Without attempting to evaluate their net desirability, there is no question but that they increased costs of production as well as potential social benefits. Then, too, the Government imposed price controls on business firms from the summer of 1971 to the spring of 1974. The price increases that were permitted on final products did not always generate a return which was sufficient to justify additional outlays to meet the Government's envirommental and safety requirements. The combined result of these Governmental interferences in the production process led many firms to close down marginal production facilities and to postpone planned expansion. Bottlenecks developed because some key inputs were unavailable.

Domestic price controls encouraged firms to export commodities, one of the most notable being fertilizer, and thereby aggravate "shortages" here. This situation was compounded, in the short run, by the depreciations of the dollar against other currencies since 1971. The depreciations changed the relative prices of domestically-produced goods and imports such that imports became more expensive in relation to U.S. goods. This led to the substitution of domesticallyproduced goods for imports, and foreign demand for U.S. products increased relative to our demand for imports. As a result, resources available to domestic industry as well as consumers have been reduced or become higher priced.

In addition, relative commodity prices changed much more than usual in 1973 and 1974 because of factors such as the drought, increased foreign food demand, and the substantial boost in oil prices. When relative prices change, consumers change their spending patterns in an effort to maximize satisfaction. Industry, however, with large fixed investment and production plans already in motion, was not able to 
make the required changes (within cost constraints) as quickly as consumers.

Hence, in early 1974 there was a surplus of certain standard-size automobiles and idle automobile capacity while consumers were seeking autos that consumed less gasoline. Also, given the large stock of existing houses and the change in relative prices, there were marked cutbacks in housing construction. At the higher interest rates which prevailed, consumers desired more of other goods and services relative to housing, which usually must be financed by sizable loans for long periods. And even if consumers were willing to pay the higher interest rates to finance housing purchases, market interferences, such as state usury laws and limitations on rates paid by thrift institutions, tended to impede further the flow of funds to housing. In contrast to the excess capacity in the auto and housing industries, firms in many other industries, such as steel, aluminum, machine tools, paper, chemical, and petrolenm, were operating at, or near, capacity for extended periods. Many, as mentioned earlier, even experienced sizable order backlogs.

In terms of industrial production, there was an abrupt reduction in output from November 1973 to February 1974 during the initial adjustment to the oil embargo. During this three-month period, production fell more than 2 percent, or at about a 9 percent annual rate. From February to October, production showed little net change, with expansion of some industries matching declines in others. Since October, production has again declined.

Total new construction expenditures, which declined slightly in the last half of 1973 , remained relatively unchanged in the first nine months of 1974 . Large Governmental outlays and private nomresidential spending about matched declines in private residential construction.

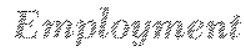

Trends in employment were mixed in 1974. On balance, total civilian employment was about unchanged from the fall of 1973 to the fall of 1974 . But at the same time, the unemployment rate increased from an average 4.9 percent of the labor force in 1973 to an average of 5.4 percent in the first eleven months of 1974. In November the unemployment rate stood at 6.5 percent. By comparison, unemployment averaged 5.8 percent of the labor force in 1971 and 1972. The increase in unemployment in 1974 while total employment continued at a high level was possible because of a sizable growth in the labor force, both as popula-

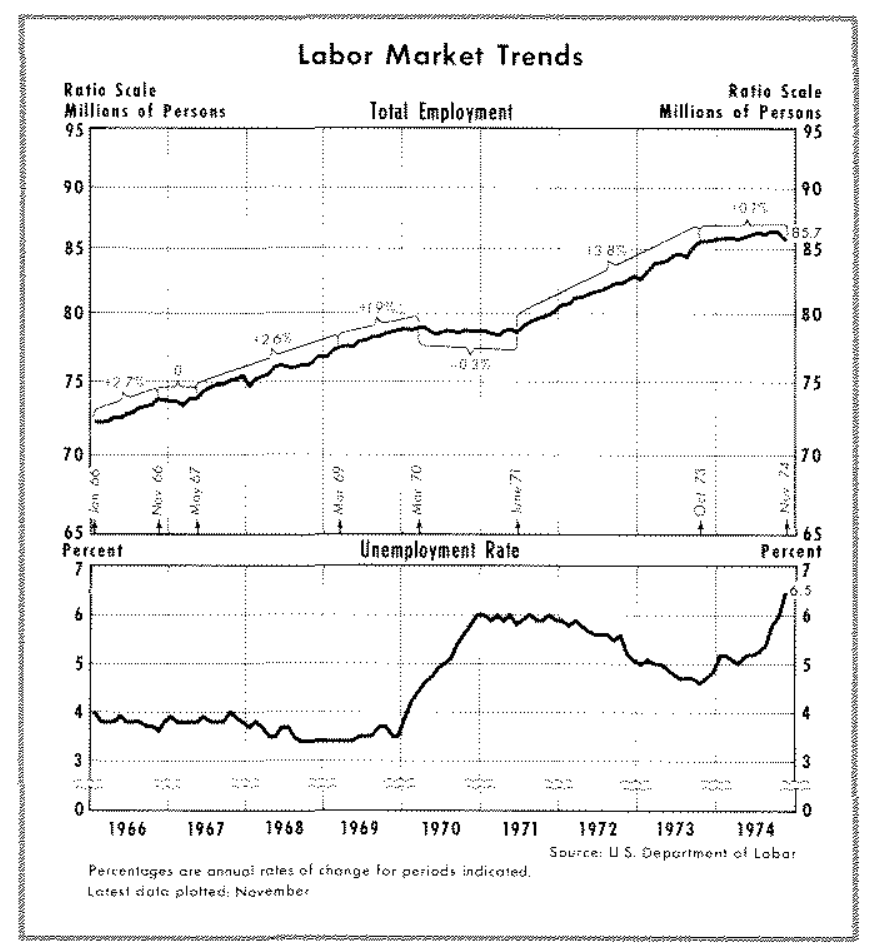

tion of labor force age grew and as the participation rate increased. Inflation probably contributed to the participation rate increase as, in some families, second and third members sought jobs to meet the higher living costs.

Output per man hour of labor fell sharply in 1974. This resulted, in part, from the sharply higher costs of energy combined with environmental and other controls which made existing capital less efficient. This, in turn, probably led some firms to substitute more labor for capital. In the first three quarters of the year, reported output per man-hour declined at about a 3 percent annual rate. By marked contrast, from early 1970 to the end of 1973 , output per man-hour rose at an average 3.3 percent rate.

The drop in labor output per hour was an important factor in the reported jump in unit labor costs, which were ap at a 13 percent annual rate in the first three quarters of 1974 . From early 1970 to the end of 1973, unit labor costs rose at a 3.8 percent rate. An additional factor contributing to the sharp rise in unit labor costs was the 10.3 percent rate of increase in wages and other compensation for the first three quarters of 1974 , compared with a 7.2 percent pace from early 1970 to the end of 1973.

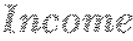

Together with greater sales and employment, nominal incomes have been rising. Total personal income 
increased at an 8 percent annual rate in the first ten months of 1974, a rate somewhat below the pace of inflation as indicated by most measures.

The bulk of total income is in the form of payments for labor services. Total wage and salary disbursements rose at a 9 percent amnual rate in the first ten months of 1974. In addition, supplements to wages and salaries, bolstered by improvements in pension plans, rose at a 14 percent rate in the same period.

Corporate profits after taxes rose at a relatively rapid 28 percent annual rate in the first three quarters of 1974. In part, the rise in reported profits reflected higher prices permitted after the removal of price controls. In view of the inflation and accounting procedures generally used, however, reported profits were probably overstated because of an inadequate handling of depreciation allowances and inventory valuation. In the 1965-70 period profits had drifted lower, and the increases in the early 1970 s have largely restored them. Profits in the third quarter of 1974 were 104 percent above their 1965 level. By comparison, over the same period wage and salary disbursements rose 113 percent.

\section{Mniston?}

Most analysts agree that inflation has been a serious, if not the most serions, economic problem of the nation. ${ }^{3}$ The increase in prices which began in the mid 1960 s was more rapid in 1974 than in any of the previous years. Average prices, as measured by the GNP price deflator, rose at an 11 percent annual rate in the first three quarters of 1974 . During 1973 prices rose 7.4 percent, and from 1965 (when the inflation began) to 1972 , prices rose at an average 4 percent annual rate. By sharp contrast, the average level of prices rose at a 1.5 percent rate from 1959 to 1965 .

The consumer price index advanced at a 13 percent anmual rate in the first ten months of 1974 after an average rise of 4.4 percent per year from 1965 to 1973 . The wholesale price index jumped at a 24 percent ammual rate in the first eleven months of 1974 , with the industrial commodity component ascending at a very rapid 28 percent rate. By comparison, wholesale prices increased at an average 4.2 percent rate from 1965 to 1973 , and the industrial commodity component went up at a 3.4 percent rate.

"In a survey of the National Association of Business Economists taken in August and September 1974, 90 percent of the 514 respondents considered inflation to be the most serious economic problem of 1974 . Government spending and conm trols received 4 percent of the vote, energy received 2 per" cent, unemployment I percent, and enviromment, exchange fates, and all others received 3 percent.

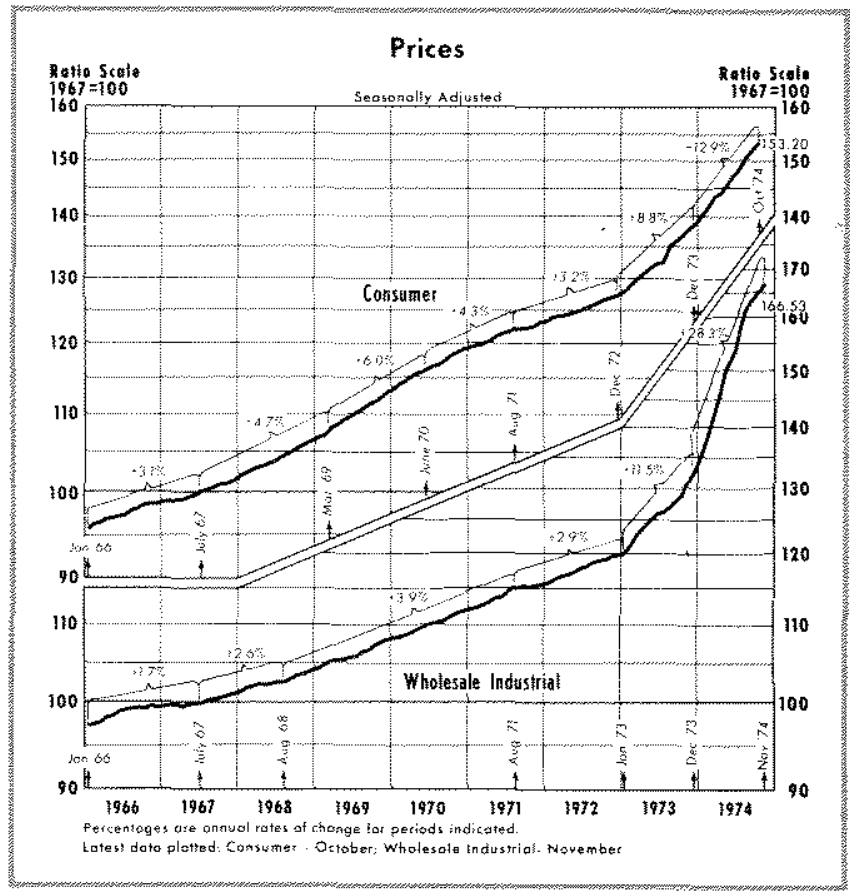

As mentioned earlier, the inflationary surge in 1974 reflected both a continued strong demand for goods and services fostered by expansionary monetary and fiscal actions taken in the 1970 through 1973 period and cutbacks in production during 1974. In addition, some of the reported price increases in 1974 were probably due to earlier inflationary pressures which were not reflected in the indexes during the period of controls. Some may even have been the result of markups made in anticipation of a reimposition of controls.

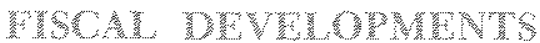

Fiscal and monetary actions taken prior to the start of 1974 have had a major influence on economic developments in the year. Actions taken during 1974 have probably played a significant role also, particularly on developments late in the year.

Federal expenditures, using the national income accounts budget, rose at a rapid 9 percent annual rate from early 1970 to late 1973 , and at a 17 percent rate in the first three quarters of 1974. This sharp rise in spending occurred despite reported efforts by the Government to restrain outlays in order to dampen inflationary pressures. National defense outlays rose at about a 5 percent rate. Defense spending has changed little, on balance, since 1968. By contrast, Social Security and other nondefense spending rose at a 19 percent rate in the first three quarters of 1974, after expanding at a 15 percent pace from early 1970 to the end of 1973. 


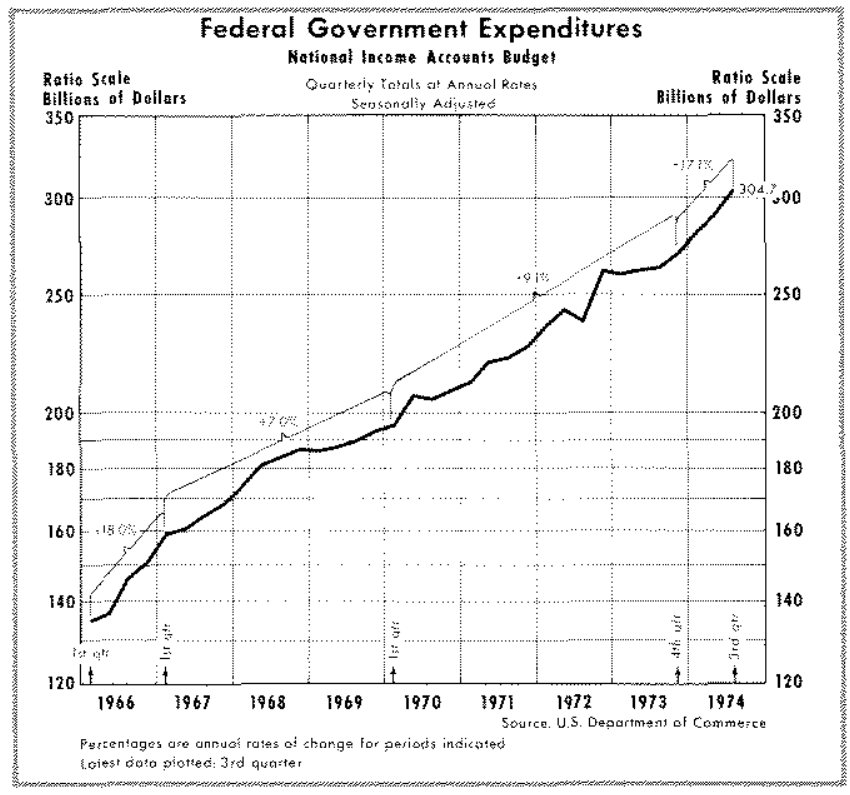

Government tax receipts also rose sharply with the inflationary expansion in individual and corporate in ${ }^{*}$ comes. For example, if a married couple with two children which had made $\$ 8,000$ per year had a 10 percent increase in income, their Federal income tax would have increased 25 percent (using the standard deduction). In the aggregate, Government receipts (national income accounts budget) increased at a 14 percent annual rate in the first three quarters of 1974.

Expenditures of the Govemment still managed to exceed the large, and expanding, tax receipts, and, as a result, the Government operated at a deficit of $\$ 3$ billion (annual rate) in the first three quarters of 1974 . The deficits in the four preceding years, however, were much larger, averaging $\$ 14$ billion.

\section{MUMren}

The nation's money stock continued to expand rapidly in the first half of 1974, but it increased only modestly after June. From the fourth quarter of 1973 to the second quarter of this year, money rose at a 6.6 percent annual rate, or at nearly the same rapid pace as in the previous four years. However, in the third quarter the growth of money slowed to a 3.6 percent rate, and from data available in early December it appears that growth in the fourth quarter will be at about a 4 percent rate.

The monetary base grew at a 7.7 percent annual rate in the first three quarters of 1974, also not significantly different from the rapid pace in the previous four years. The multiplier (a mathematical concept which statistically links monetary base and money) declined during the second half of this year, primarily

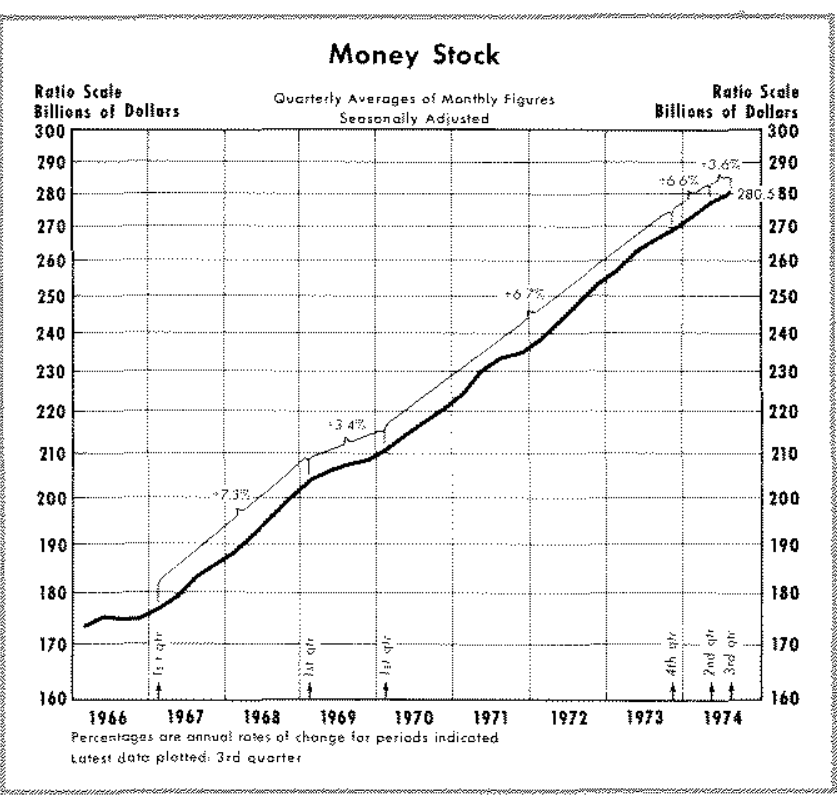

reflecting a rise in currency relative to demand deposits.

Money plus net time deposits, a broader measure that some analysts find useful, rose at a 9 percent annual rate in the first two quarters of 1974 . This rate also was approximately the same as in the four previous years. During the third quarter, money plus net time deposits increased at a reduced 6.2 percent rate.

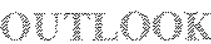

As 1974 ends, the pace of inflation appears to be moderating, but production has declined and unemployment has been rising. Based on the momentum of business developments and stabilization actions taken to date, the rate of inflation will probably be less in 1975 than in 1974. Early in 1975, production is likely to remain sluggish, and unemployment will probably average somewhat higher than in the last half of 1974. However, a major contraction, which some persons fear, does not appear likely, and, as the year progresses, production and employment growth should gradually improve. (Of course, developments in 1975, especially later in the year, will be affected, to some extent, by stabilization actions taken during the year.)

Although progress toward price stability and resumed economic growth is anticipated during 1975 , it serves no purpose to pretend that there is a quick, easy, and costless cure to our economic disarray. Progress is likely to be slow, since the lagged effects of past monetary and fiscal actions and economic developments will impinge on the economy for some time. 
In addition, progress toward price stability and economic growth is likely to be slow because the economy continues to be hobbled by Governmental restrictions. Available resources, such as oil, have been. reduced, and social objectives have been given a higher priority relative to economic growth in a number of areas. For example, measures to clean the air and water have been adopted at the cost of less output of goods and services. Many of the handicapped, youth, and unskilled remain idle rather than being permitted to accept a job at wages below the established minimum standard. Also, incentives probably have been dulled as a smaller portion of economic rewards go to those who produce and a larger portion go to others deemed deserving on humanitarial grounds.

At times, however, interferences to real economic expansion have been reduced or eliminated. During 1974 , for example, a reversal of policy occurred which should contribute significantly to the resiliency of the economy and improved economic growth. In the spring of 1974 wage and price controls were removed. These controls had been ineffective since they treated only the symptoms of inflation and not the basic canses. The controls were easily evaded, if not by open defiance or black markets, then by reducing quality or service or by redefining products. Controls were a drag on the economy since they reduced work and production incentives. As a result, productivity decreased and capital investment was discouraged or misdirected into areas where controls were weakest. Since there was a cost of administration, those that did produce were taxed to support the system.

\section{(W) Bry}

Inflation, which began in the mid 1960 s, has been the nation's most serious economic problem this past year. The acceleration of inflation was moderate in the $1960 \mathrm{~s}$, but in 1973 and 1974 there was a pronounced upward surge in prices, reflecting both a continuation of rapid spending increases combined with a reduction in output.

During 1974 policies were implemented to moderate the spending increases and to foster a more rapid expansion in production. Monetary actions have bem come somewhat less expansionary. Wage and price controls were eliminated. In addition, the private sector of the economy has made great strides toward adapting to the higher prices of energy and energyrelated products.

The rate of inflation could be slowed more quickly and production could be expanded more rapidly by improving the market system, but such improvements may conflict with other objectives. Actions to improve economic efficiency and incentives include reducing subsidies, tarifs and import quotas, widening the range of anti-trust laws to cover more monopolistic practices of business as well as labor, eliminating oatdated building restrictions and other barriers to greater production, improving skills of workers and information on job openings, and modifying minimum wage laws in the interest of improving job opportunities for the inexperienced and handicapped.

A "fine-tuning" of the economy camnot be attained with the present state of economic knowledge, and vigorous efforts to do so may actually be destabilizing. Policymakers have incomplete and delayed information on economic developments, and there are lags in the effect of stabilization actions taken. However, if destabilizing actions can be avoided, substantial progress should be made during 1975 toward the goals of high employment and stable prices.

\section{THE U. S. BALANCE OF PAYMENTS DURING 1974}

HANS H. HELBLING

During 1974 U. S. international transactions were affected mainly by four forces:

1) the sharply increased petroleum prices in world markets,

2) the adjustments to exchange rate changes which have occurred since 1971 ,
3) the cyclical downturn in many industrial countries,

4) and the high, though differential, rates of monetary growth and inflation throughout the world.

These factors are interrelated and have exerted both favorable and unfavorable pressures on the U. S. 


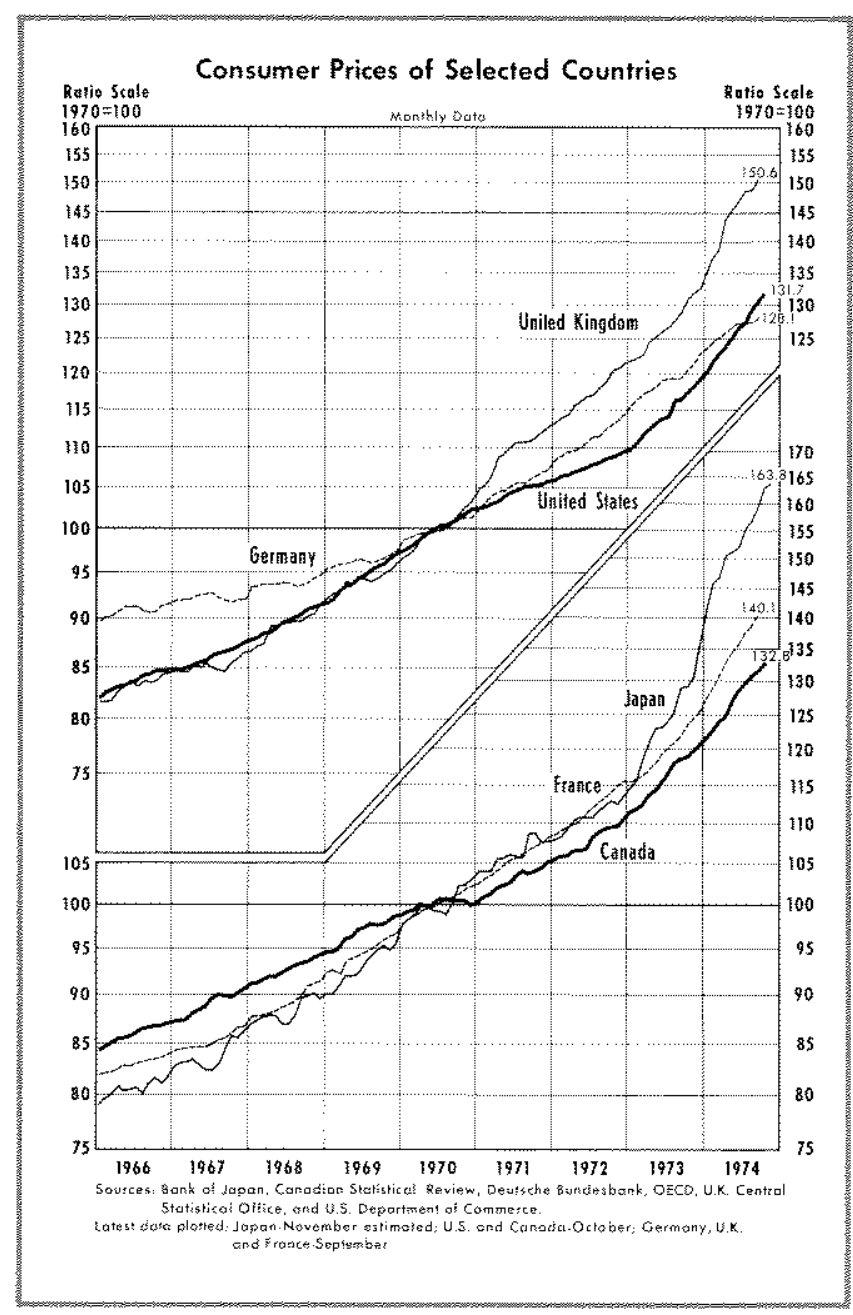

international accounts; it is not always possible, however, to isolate the individual effects quantitatively. The higher oil prices and a relatively inelastic demand for ofl imports had the effect of increasing sharply the vatue of U. S. merchandise imports. The dollar depreciation since 1971 changed the relationship between the price of imports and the price of domesticallyproduced goods. This encouraged exports of domestically-produced goods and discouraged imports. The cyclical downtum in both the United States and its trading partners had the effect of retarding the growth rates of both U. S. demand for imports and foreign demand for our exports. The differential rates of inflation, to the extent that they were not already accounted for in exchange rate movements, had a tendency to promote $U$. S. exports since the U. S. rate of inflation was lower, on average, than that of its competitors.

\section{Trade Palanee}

After substantial trade surpluses in December 1973 and January 1974 the $U$. S. trade balance moved into

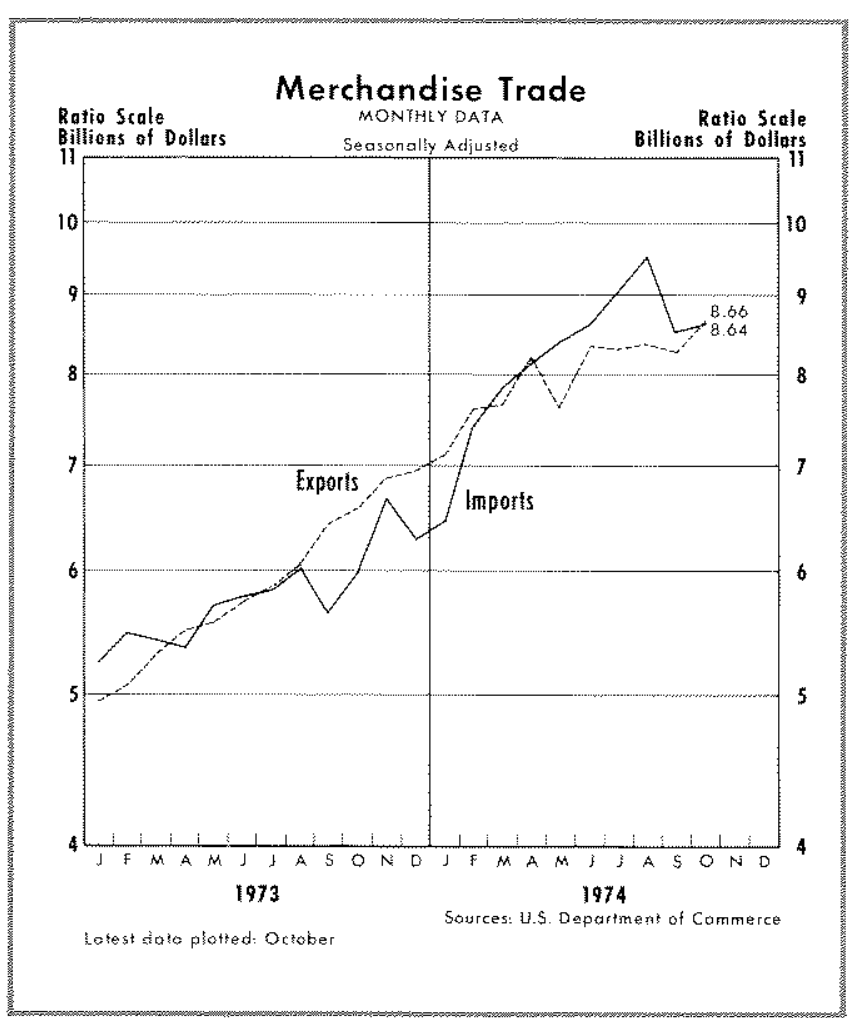

deficit. $^{1}$ For the first ten months of this year the cumulative trade deficit amounted to $\$ 2.8$ billion. Import prices of petroleum increased at a very rapid rate while the quantity imported was only slightly below 1973 levels. This suggests that the trade deficit was affected substantially by the rise in oil prices. Removal of petroleum transactions from the trade balance reveals that the balance on other transactions is still in substantial surplus, although the surplus declined somewhat from its peak in March 1974.

A reduction in the valne of agnicultural exports since mid-1974 also contributed to the declining trade balance. This occurred as both the quantity and the price of exports declined from the extremely high values of 1973. Since mid-1974, however, prices of U. S. agricultural commodities lave been rising again, such that the recent decline in the value of agricultural exports should be reversed in coming months.

Use of somewhat more detailed trade data (available at this time only through the second quarter of 1974 ) reveals that manufactured goods contributed positively to the U.S. trade balance. The sustained strength of exports of U. S. manufactured goods was probably the result of continued U. S. comparative

${ }^{1}$ All balance-of-payments data are reported at seasonally ad. justed annual rates. Monthly trate data are avallable only through October. All other data, except for the basic and goods and services balances, are available through the thitd quarter. 
advantage in the production of these goods combined with large investment spending by major industrial countries.

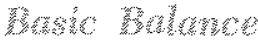

In addition to the trade balance, the basic balance includes net income from investments abroad and other services, unilaterial transfers, and the balance on long-term capital flows." For the first half of 1974, the basic balance was in deficit by $\$ 1.9$ billion, compared to a $\$ 0.9$ billion deficit during 1973.

A major factor contributing to the basic balance deficit was the shift in the trade balance from a small surplus in 1973 to a deficit in 1974 . Net investment income, however, increased from $\$ 5.3$ billion in 1973 to $\$ 9.7$ billion for the first half of 1974 . Income from U. S. investments abroad amounted to $\$ 24.8$ billion in the first half of 1974, considerably greater than the $\$ 14$ billion recorded in 1973. At the same time, income payments to foreigners on their investments in the United States amounted to $\$ 15,1$ billion over this period, compared to only $\$ 8.7$ billion in 1973.

Part of the increase in U. S. investment income from abroad is related to the fact that interest rates abroad were higher in 1974 than in 1973. Also, higher U. S. interest rates and larger stocks of foreign assets held in the United States (both direct and portfolio investment) influenced the sharply higher income payments to foreigners. Both the increased U.S. investment income and the increased income payments to foreigners were significantly influenced by petroleum-related transactions. The sharply increased oil prices contributed to increased earnings of $U$. S. oil companies operating abroad while the larger degree of participation of oil exporting countries in U. S. oil company assets added to the increased income payments to foreigners. On the whole, $\$ 7$ billion of the $\$ 9.7$ billion net investment income from abroad during the first half of 1974 resulted from petroleumrelated transactions."

U. S. direct investment abroad amounted to $\$ 4.4$ billion in the first half of 1974 , slightly lower than the 1973 outflow of $\$ 4.9$ billion. Inflows of foreign capital for direct investment in the United States increased sharply to $\$ 5.6$ billion in the first half of 1974 , compared to $\$ 2.5$ billion in 1973 . The change in foreign direct investment inflows from 1973 to 1974

2Data for the basic balanoe, at this time, is available only through the second quarter of 1974.

3 Survey of Current Business (September 1974), p. 37. is mainly accounted for by oil related transactions while other foreign direct investment inflows changed little relative to $1973 .^{4}$

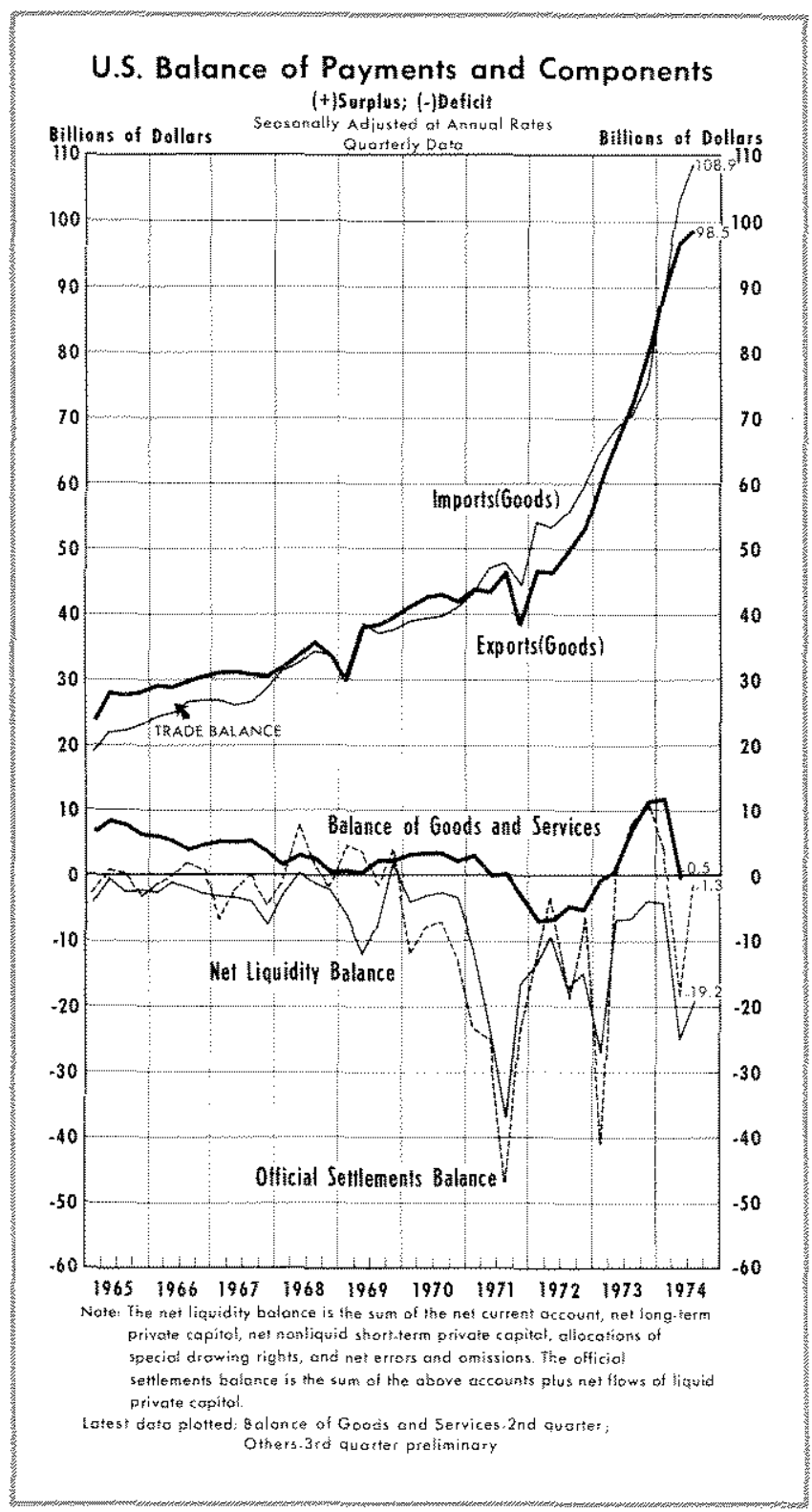

The U.S. basic balance is generally considered to be an indicator of underlying, or long-term, trends in the U. S international economic position. However, because of the special influence of increased oil prices, this balance should be interpreted with caution, as should be the trade balance.

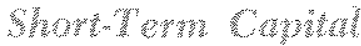

Net outflows of nonliquid short-term capital, mainly U. S. bank loans to foreigners, increased

4 Ibid., p. 40. 
sharply during the first three quarters of 1974 . They climbed from $\$ 4.5$ billion in 1973 to $\$ 14.2$ billion so far in 1974. A number of factors contributed to this development: higher interest rates in many foreign countries (including the Eurodollar market) relative to U. S. rates, increased loan demand on the part of many countries to meet oil import payments, and the removal of U.S. controls on capital outflows early in the year. During the third quarter, however, U. S. bank loans to foreigners were considerably smaller that in both the first and second quarters, despite the relatively lower U.S. interest rates. The third quarter reduction may be related to a leveling-off in foreign loan demand from the second quarter. The second quarter bank loan figures were affected by a very sharp run-up in the volume of oil shipments, followed by a return to more normal volumes in the third quarter.

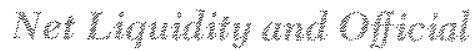

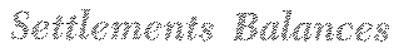

The net liquidity deficit may be thought of as the total of U. S. dollar balances which accrue to foreigners during an accomting period as a result of all of the above transactions. For the first three quarters of 1974 , this balance was in deficit by $\$ 16.1$ billion, compared to a $\$ 7.6$ billion deficit for 1973 .

The official settlements balance, on the other hand, is intended to measure only dollar balances which accrue to foreign official institutions. During the first three quarters of 1974 the official settlements baIance registered a deficit of $\$ 5.1$ billion, compared to a $\$ 5,3$ billion deficit for 1973 .

The difference between the net liquidity balance and the official settlements balance is due to dollar balances held by private foreign residents. Thus, for the first three quarters of 1974 private foreign residents acquired dollar balances amounting to $\$ 11$ billion.

A word of caution is in order with respect to these two balances. The official settlements balance was originally designed to reflect the extent of official intervention in the foreign exchange market during a given period. Under the previous system of fixed exchange rates, monetary authorities were required to intervene in foreign exchange markets in order to maintain the agreed upon dollar exchange rate. Under the current system of flexible exchange rates, such official intervention is no longer required.

In addition, it should be kept in mind that foreign official institutions may acquire dollar holdings for reasons other than those relating to exchange market intervention. The rapid accumulation of claims on the United States by the members of OPEC (Organization of Petroleum Exporting Countries) is a case in point. The increased holding of dollar claims by OPEC governments reflects a conscious investment decision to hold dollar denominated assets, rather than the effects of market intervention in support of the dollar exchange rate.

Moreover, the magnitudes of both the net liquidity and the official settlements balances are affected strongly by the recycling of oil funds. For example, if foreigners borrow in the United States to finance their oil import bill, these transactions would be recorded as capital outflows giving rise to a net liquidity deficit. Ultimately, however, the proceeds from such borrowing may end up with the governments of oil exporting countries who would place these funds on deposit in the United States. This type of transaction would therefore give rise to $U, S$, deficits on both the net liquidity and the official settlements balances, when in fact they reflect the role of the United States as an exporter of the services of a financial intermediary.

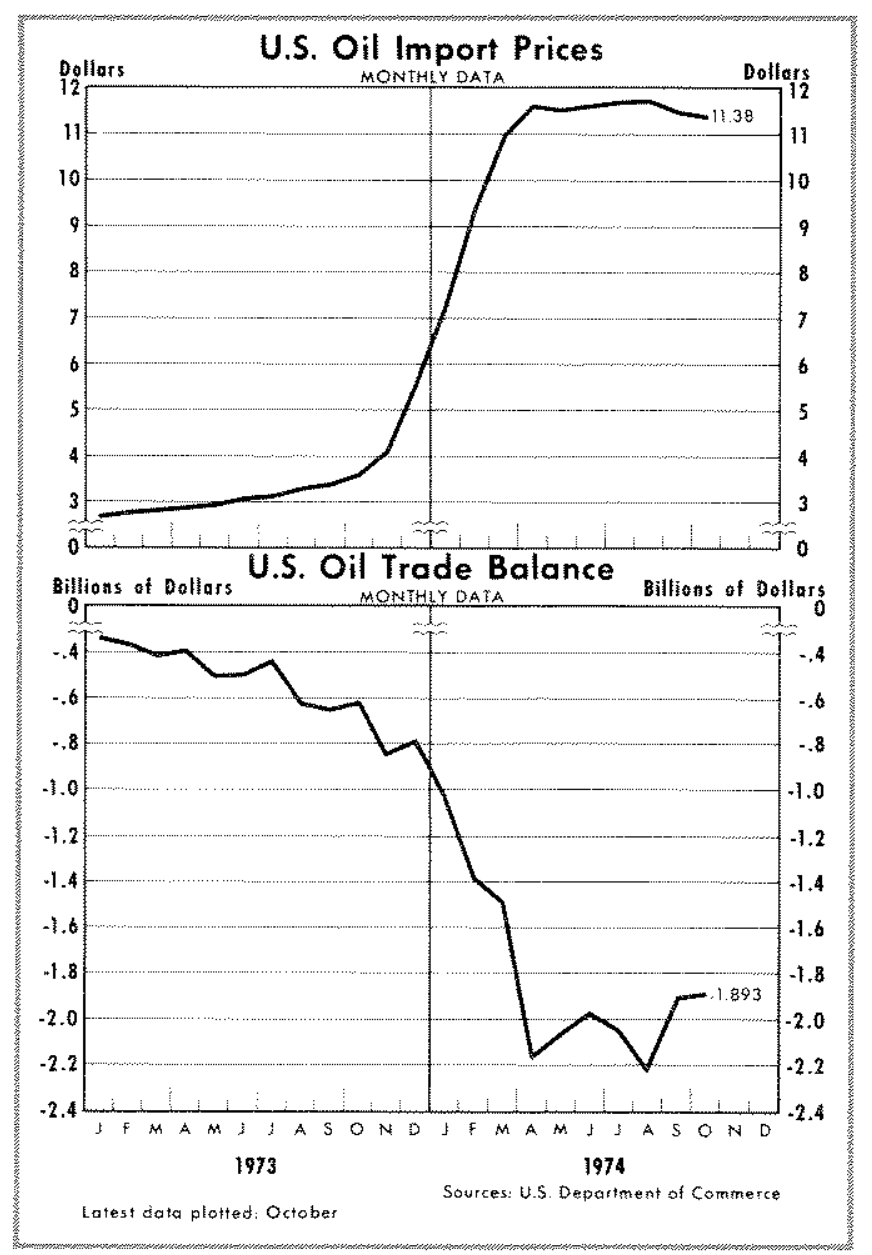




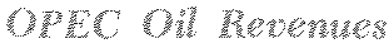

There has also been considerable interest concern" ing the total dollar accrual of oil revenues by OPEC and the disposition of these oil revenues. The U. S. Treasury Department reports that between January and September 1974, the members of OPEC collectively acquired dollar balances amounting to $\$ 35$ billion. About $\$ 8$ billion was placed directly in the United States while the remainder was invested in other countries and in the Eurocurrency market.

It should be noted that although only $\$ 8$ billion of OPEC funds was placed directly in the United States by OPEC members, at least a portion of the remainder could have been placed in the United States by other parties. For example, if an OPEC member desires to deposit its dollar balances in the Eurodollar market, then immediate control of those dollar balances would be transferred to the Eurodollar banks instead of the OPEC member. If Eurodollar banks extend dollar denominated loans such that the loan proceeds are used to buy real and financial assets in the United States, indirect investment of OPEC dollar balances would have occurred.

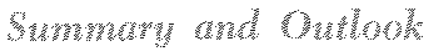

The U. S. trade balance was in deficit by $\$ 2.8$ bil. lion in the first ten months of 1974 . The basic balance deficit for the first half of 1974 amounted to $\$ 1.9$ billion, and for the first three quarters the net liquidity and official settlements deficits amounted to $\$ 16.1$ and $\$ 5.1$ billion, respectively.

The trade deficit can be attributed to the sharp increase in oil prices. In fact, when the infuence of higher oil prices is removed there emerges an improved U. S. trade balance as compared to last year. Prospects for 1975 suggest that the U. S. merchandise trade balance, because of oil payments and a somewhat lower volume of agricultural exports, can be expected to remain in deficit.

The basic balance, however, will be heavily infuenced by the actions of OPEC regarding the disposition of their large and accumulating dollar balances. Should they decide to invest their dollar balances in long-term instruments, and depending on their magnitude, the basic balance could be in equilibrium or perhaps even in surplus. The net liquidity balance may be expected to be much the same as the basic balance if $\mathrm{U}$. $\mathrm{S}$. bank lending to foreign oil importing countries subsides. At this time it is not

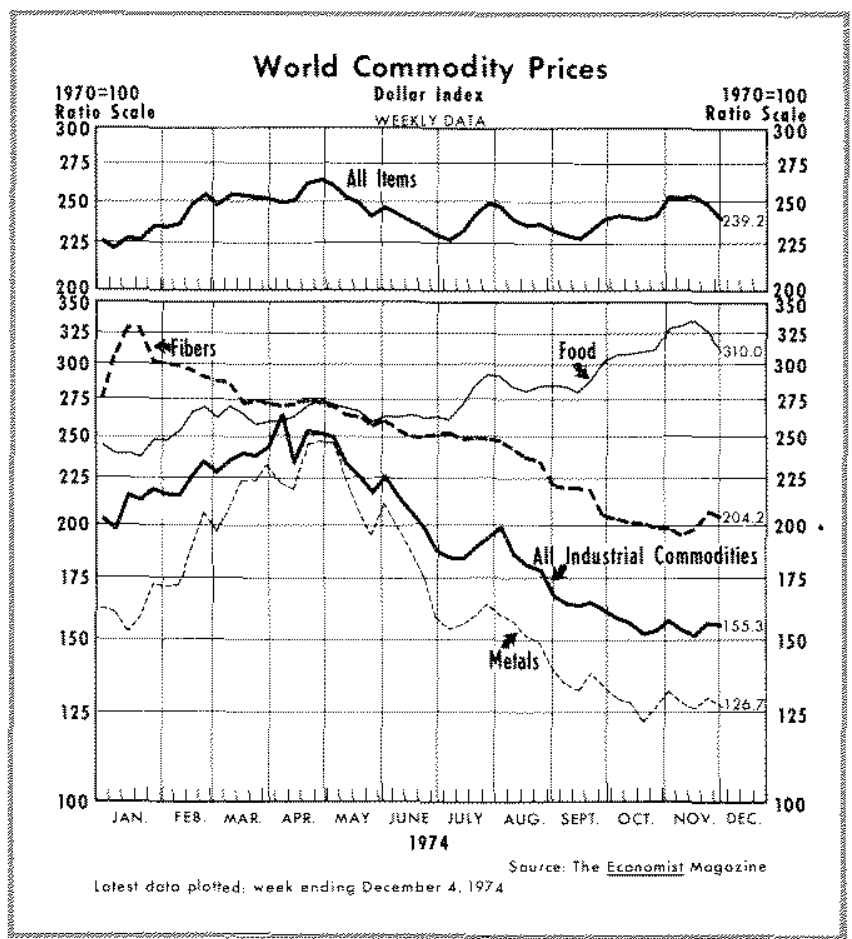

clear how U.S. participation in any new oil financing facility would be recorded in the U. S. balance of payments. To the extent that any such U. S. participation would be recorded "below the line," netting U. S. claims against U. S. liabilities, a net liquidity deficit would not materialize as a result of these U. S. oil loans.

In addition, if foreign oil exporting countries do decide to hold their dollar aceruals in long-term form, rather than short-term, the official settlements balance could also be expected to be in equilibrium, In fact, a possibility exists that the official settlements balance might even be in surplus. This possibility is enhanced if foreign countries, who now possess stocks of liquid dollar reserves, transfer them to OPEC, who in turn would place them in the United States as long-term investments.

Projections concerning the dollar exchange rate are difficult at this time. As a result of a strong demand for U. S. dollars on the part of many foreign countries to finance oil deficits and the relatively low rate of monetary growth in the United States, the dollar could be expected to appreciate somewhat. However, due to a general reluctance on the part of countries to allow their currencies to depreciate relative to the dollar, this dollar appreciation might not be enough to offset fully the effect of differential rates of money growth and inflation. 